\title{
Angiotensin II type 1 receptor antibodies in kidney transplantation
}

\author{
Hyeyoung Lee', Eun-Jee $\mathrm{Oh}^{2}$ \\ ${ }^{1}$ Department of Laboratory Medicine, International St. Mary's Hospital, College of Medicine, \\ Catholic Kwandong University, Incheon, Korea; \\ ${ }^{2}$ Department of Laboratory Medicine, Seoul St. Mary's Hospital, College of Medicine, \\ The Catholic University of Korea, Seoul, Korea
}

\begin{abstract}
Angiotensin II type 1 receptor (AT1R) antibodies directly injure endothelial and vascular smooth muscle cells by activating transcription factors associated with proinflammatory responses. Previous studies have shown that AT1R antibodies are associated with allograft rejection and decreased graft survival in kidney transplantation. Development of enzyme-linked immunosorbent assay has facilitated semiquantitative detection of AT1R antibodies. Assessing AT1R antibodies along with donor specific human leukocyte antigen antibodies may have potential to identify patients with possible risk for allograft injury and improve overall outcomes. In this review, we summarize recent clinical studies about AT1R antibodies in kidney transplantation and provide perspectives for future research area.
\end{abstract}

Keywords: Transplantation; Receptor; Angiotensin, type 1; Kidney

\section{INTRODUCTION}

Kidney transplantation (KT) is an ideal treatment for patients with chronic kidney disease. The survival rate of allografts has been greatly improved due to the development of surgery and organ preservation techniques as well as immunosuppressants [1]. However, antibody-mediated rejection (AMR) is a major cause of graft failure and donor-specific human leukocyte antigen antibody (DSA) is known to be the most important risk factor for AMR [2]. With recent development of solid-phase assay using Luminex platform that can facilitate the detection of DSA, DSA monitoring is being used widely to predict rejection and outcome of transplantation [3]. Nevertheless, not all detected DSAs would adversely affect the prognosis of

Received March 11, 2019

Accepted March 13, 2019

Correspondence to: Eun-Jee Oh

Department of Laboratory Medicine, Seoul St. Mary's Hospital, College of Medicine, The Catholic University of Korea, 222 Banpo-daero, Seocho-gu, Seoul 06591, Korea

Tel: +82-2-2258-1641, Fax: +82-2-2258-1719

E-mail: ejoh@catholic.ac.kr transplantation [4-6]. In addition, AMR in patients without DSA has been reported and the clinical significance of non-human leukocyte antigen (HLA) antibodies has been noted $[7,8]$.

Angiotensin II type 1 receptor (AT1R) antibody is the most widely studied non-HLA antibody until recently. Its association with graft rejection and graft failure has been reported [8-14]. AT1R is expressed on the surface of endothelial cells and combines with angiotensin II to regulate water-salt balance and blood pressure [15]. AT1R antibodies are known to act directly on endothelial cells and smooth muscle cells, consequently activating transcription factors associated with inflammatory reactions and damaging the transplant kidney [16]. In this article, we will review the clinical significance of AT1R antibodies in KT based on recent literatures.

\section{PATHOPHYSIOLOGY}

AT1R belongs to the rhodopsin group (family A), one of $G$ protein-coupled receptors composed of seven trans- 
membrane domains that can penetrate cell membranes and a loop that connects them [16]. AT1R-encoding gene is located on chromosome 3, composed of four exons. The expression level of AT1R antigen is determined by mRNA expression controlled by different splicing types of each exon [17]. The most well-known polymorphism that controls the expression of AT1R is A1166C known to increase responsiveness to angiotensin II. A1166C is also associated with various cardiovascular and renal pathophysiology [18].

AT1R modulates blood pressure and water-salt balance by mediating the physiological action of angiotensin II in various organs including the kidney. Angiotensin II promotes vasoconstriction, thrombosis, inflammation, and fibrosis [19-21]. A small amount of AT1R is constitutively expressed on endothelial cells of tissues. Its expression increases when cells are activated [22]. Antibodies to AT1R were first detected in patients with pre-eclampsia [23] and first reported in kidney transplant recipients suffering severe steroid-resistant vascular rejection and malignant hypertension without DSA [8]. It is known that AT1R antibodies can respond to both autoantigen and alloantigen. AT1R autoantibodies are induced by the transplantation process, ischemia, and inflammation caused by infection [24-26]. Similar to HLA antibodies, AT1R antibodies can also be induced by blood transfusions, pregnancies, previous transplantation, and any interruption of immunosuppressive agents $[7,8,13,22]$.

\section{MECHANISM OF GRAFT INJURY BY AT1R ANTIBODIES}

AT1R antibodies can directly bind to endothelial and vascular smooth muscle cells and activate transcription factors associated with proinflammatory responses via extracellular signal-regulated kinase (ERK) $1 / 2$ cascades $[8,16]$. The ERK $1 / 2$ pathway is known to play a variety of roles, including regulation of cell adhesion, migration, survival, and proliferation [1]. Dragun et al. [8] have demonstrated that AT1R antibodies can enhance the phosphorylation of ERK 1/2 kinase in vascular smooth muscle cells and increase DNA binding of transcription factor activator protein 1 and nuclear factor-kB. In addition, biopsy of rejected patients who had AT1R antibody showed strong staining of tissue factor in vascular epithelial cells, endothelial cells, and glomerular stromal cells without complement activation. Tissue factor is known to activate blood coagulation cascade, suggesting that tissue factor induced by AT1R antibody can act as an important mechanism for vascular rejection [8]. A recent study has reported that levels of tumor necrosis factor- $\alpha$, interleukin (IL)-8, and IL- $1 \beta$ are significantly higher in posttransplant serum of patients with AT1R antibodies than those in controls [13], supporting the association of AT1R antibodies with inflammation.

DSA can induce rejection through complement activation and antibody-dependent cell mediated cytotoxicity [16]. AT1R antibody is mainly composed of immunoglobulin G3 (IgG3) and IgG1 isotypes known to be related to complement activation. Nonetheless, most biopsy findings from AT1R antibody-positive patients with acute or chronic graft dysfunction have shown C4d-negative $[8,9]$. Histologic findings of damaged graft by AT1R antibodies have revealed microvascular inflammation (MVI) to endarteritis, fibrinoid necrosis, and arterial thrombosis [8].

Recently, it has been reported that HLA and non-HLA antibody can interact each other to promote the rejection process [25]. Whether AT1R antibody can act alone or in combination with DSA has not been clearly elucidated. However, in patients with both DSA and AT1R antibodies, the survival rate is lower [11], the incidence of MVI is higher [14,27], and the decline of estimated glomerular filtration rate (eGFR) after transplantation is more rapid [28] than those in patients with DSA alone, suggesting that synergistic action of both DSA and AT1R antibodies may negatively affect the prognosis.

\section{MEASUREMENT OF AT1R ANTIBODY}

AT1R antibody was first measured by chronotropic bioassay to determine the heart rate of myocardial cells after AT1R-IgG mediated stimulation of cultured myocardial cells [23]. Subsequently, an enzyme-linked immunosorbent assay (ELISA) based assay was developed to detect AT1R antibodies [9]. The performance of anti-AT1R ELISA has been reported to have a sensitivity of $88 \%$, a specificity 
of $100 \%$, an inter-assay variation of $8 \%$, and an intra-assay variation of $5 \%[9,10]$. The principle of the ELISA is to attach the extracts of AT1R-transfected Chinese hamster ovary cell to a 96-well plate, react with AT1R antibody in the serum, and then measure AT1R antibody levels using an enzyme-conjugated secondary antibody. Measured absorbance is then compared with a standard curve to obtain the index value of AT1R antibody semiquantitatively. Currently, there is no standardized cutoff value to determine AT1R antibody positivity. Previous studies have reported various cutoff values of 9 [12,29], 10 [10,30,31], 15 [11], and $17 \mathrm{U} / \mathrm{mL}[13,32,33]$, making it difficult to compare results of previous studies. The incidence of AT1R antibody detection in pretransplant patients has been reported to be $22 \%-59 \%$ [10,12,14,29,32]. The incidence of de novo AT1R antibody detection has reported to be $3 \%$ in adult recipients [11] and $26 \%$ in pediatric recipients [13]. Cutoff values and results of previous studies are summarized in Table 1 [8-14,27-38].

\section{PRETRANSPLANT AT1R ANTIBODY}

In 2013, Giral et al. [10] detected AT1R antibodies in 283 of 599 pretransplant recipients (47\%). They found that pretransplant AT1R antibody was an independent risk factor for rejection within 4 months after transplantation and late transplantation failure after 3 years or more. A multicenter study in Korean KT recipients has shown that 59\% of patients are positive for pretransplant AT1R antibody and that pretransplant AT1R antibody can increase the incidence of acute rejection by 3.2-fold within 1 year after transplantation [12]. A study conducted on 117 recipients by Banasik et al. [29] has also confirmed that the detection of AT1R antibody prior to transplantation is an important risk factor for graft failure, suggesting the need for AT1R antibody monitoring before transplantation. Cuevas et al. [34] have reported that high-levels (>30 U) of AT1R antibodies measured in pretransplantation are associated with early development of de novo DSA after transplantation. A study of 359 Korean kidney transplant patients by Min et al. [14] has identified pretransplant AT1R antibody as a risk factor for the development of MVI and graft failures. It also revealed MVI findings in most recipients who devel- oped graft failure and had pretransplant AT1R antibody. Philogene et al. [32] have reported that serum creatinine levels at 3 months posttransplantation are significantly higher and abnormal histologic findings are more rapidly detected in patients with pretransplant AT1R antibody compared to those in patients without AT1R antibody. However, Deltombe et al. [35] have reported that AT1R antibody is not associated with rejection or graft failure in 940 recipients. Thus, further study is needed to determine the clinical significance of pretransplant AT1R antibodies.

\section{POSTTRANSPLANT AT1R ANTIBODY}

Dragun et al. [8] first reported the association of the detection of AT1R antibody after KT with rejection. Reinsmoen et al. [9] have measured AT1R antibodies using a commercially available ELISA assay and sera from 63 renal transplant recipients with negative DSA and major histocompatibility complex class I chain-related gene A (MICA) antibodies. AT1R antibodies were detected in six of seven AMR patients, suggesting that AT1R antibodies could trigger rejection process independently without DSA [9]. However, Giral et al. [10] have reported that only four (18\%) of 22 patients with pretransplant AT1R antibodies are positive for AT1R antibodies at the time of rejection. Banasik et al. [29] have reported that AT1R antibody titer is decreased after transplantation compared to that before transplantation. These data suggest that AT1R antibodies can be adsorbed to the graft at the time of rejection, similar to HLA antibody, and the amount of AT1R antibody detected in the actual serum is low [10,39]. Taniguchi et al. [11] have compared 134 rejected patients to 217 control patients and reported that de novo AT1R antibodies are related to graft failure. Fichtner et al. [28] have found that AT1R antibody alone is positive in $21 \%(6 / 28)$ of rejection patients while AT1R antibody and DSA are both positive in 57\% (16/28) of rejection patients among 62 pediatric recipients more than 1 year after transplantation. They also reported that eGFR decline after transplantation in patients with both AT1R antibodies and DSAs was more rapid than that in patients who were only AT1R antibody positive or DSA positive. Sas et al. [40] have observed 
Table 1. AT1R antibodies in KT

\begin{tabular}{|c|c|c|c|c|}
\hline Study & No. of recipients & Time of detection & Cutoff & Key finding \\
\hline $\begin{array}{l}\text { Dragun et al. } \\
(2005) \text { [8] }\end{array}$ & 33 With rejection & Post-KT & NA (bioassay) & $\begin{array}{l}16 \text { Patients with malignant hypertension and } \\
\text { rejection had AT1R } \mathrm{Ab}(+) \mathrm{DSA}(-) \text { AT1R } \\
\mathrm{Ab}(+) \mathrm{DSA}(-) \text { patients had rapid allograft } \\
\text { loss than AT1R } \mathrm{Ab}(-) \mathrm{DSA}(+) \text { patients. }\end{array}$ \\
\hline $\begin{array}{l}\text { Reinsmoen et al. } \\
\text { (2010) [9] }\end{array}$ & $\begin{array}{l}63 \text { With no DSA or } \\
\text { MICA-DSA }\end{array}$ & Pre \& post-KT & 17 Units & $\begin{array}{l}\text { Six of } 7 \text { AMR patients had AT1R } \mathrm{Ab}(+) \text { at } \\
\text { post-KT. }\end{array}$ \\
\hline $\begin{array}{l}\text { Giral et al. } \\
\text { (2013) [10] }\end{array}$ & 599 & Pre-KT & $10 \mathrm{U}$ & $\begin{array}{l}\text { Pre-KT AT1R Ab was associated with acute } \\
\text { rejection and increased graft failure after } \\
3 \text { years post-KT. }\end{array}$ \\
\hline $\begin{array}{l}\text { Taniguchi et al. } \\
\text { (2013) [11] }\end{array}$ & $\begin{array}{l}\text { 351: } 134 \text { With } \\
\text { rejection, } 217 \text { control }\end{array}$ & Pre \& post-KT & $15 \mathrm{U} / \mathrm{mL}$ & $\begin{array}{l}\text { De novo AT1R Ab was associated with graft } \\
\text { failure. }\end{array}$ \\
\hline $\begin{array}{l}\text { Banasik et al. } \\
\text { (2014) [29] }\end{array}$ & 117 & Pre \& post-KT & $9 \mathrm{U} / \mathrm{mL}$ & $\begin{array}{l}\text { Pre-KT AT1R Ab was risk factor for graft } \\
\text { failure. Patients with AT1R Ab showed more } \\
\text { severe Banff grade. }\end{array}$ \\
\hline $\begin{array}{l}\text { Fuss et al. } \\
\text { (2015) [31] }\end{array}$ & $\begin{array}{l}11 \text { With C4d negative } \\
\text { antibody mediated } \\
\text { rejection without DSA }\end{array}$ & Pre \& post-KT & $10 \mathrm{U} / \mathrm{mL}$ & $\begin{array}{l}\text { All patients had pre-KT or post-KT AT1R Ab } \\
(+) \text {. All patients responded to anti-rejection } \\
\text { therapy, which included plasma exchange and } \\
\text { angiotensin receptor blocker therapy. }\end{array}$ \\
\hline $\begin{array}{l}\text { Lee et al. } \\
\text { (2015) [30] }\end{array}$ & 53 With rejection & Post-KT & $10 \mathrm{U} / \mathrm{mL}$ & $\begin{array}{l}\text { AT1R Ab was associated with HLA class-I DSA. } \\
\text { Presence of both AT1R Ab(+) and DSA( }(+) \\
\text { was associated with AMR. }\end{array}$ \\
\hline $\begin{array}{l}\text { Lee et al. } \\
\text { (2015) [36] }\end{array}$ & 75 With AMR & Pre \& post-KT & $15 \mathrm{U} / \mathrm{mL}$ & $\begin{array}{l}\text { Nine patients were pre-KT AT1R } \mathrm{Ab}(+) \text { and } 10 \\
\text { patients were AT1R } \mathrm{Ab}(+) \text { at the time of biopsy. }\end{array}$ \\
\hline $\begin{array}{l}\text { Cuevas et al. } \\
\text { (2016) [34] }\end{array}$ & 141 & Pre-KT & $10,17,30 \mathrm{U}$ & $\begin{array}{l}\text { Higher }(>30 \mathrm{U}) \text { pre-KT AT1R Ab were risk } \\
\text { factor for earlier development of de novo DSA. }\end{array}$ \\
\hline $\begin{array}{l}\text { Deltombe et al. } \\
\text { (2017) [35] }\end{array}$ & 940 & Pre-KT & $10,17 \mathrm{U} / \mathrm{mL}$ & $\begin{array}{l}\text { Did not confirm of association between pre-KT } \\
\text { AT1R Ab with transplant outcome. }\end{array}$ \\
\hline $\begin{array}{l}\text { Lee et al. } \\
\text { (2017) [12] }\end{array}$ & 166 & Pre-KT & $9.05 \mathrm{U} / \mathrm{mL}$ & $\begin{array}{l}\text { Pre-KT AT1R Ab was risk factor for acute } \\
\text { rejection, especially acute cellular rejection. }\end{array}$ \\
\hline $\begin{array}{l}\text { Lim et al. } \\
\text { (2017) [37] }\end{array}$ & $\begin{array}{l}27 \text { With rejection } \\
\text { and no DSA }\end{array}$ & Pre-KT & $17 \mathrm{U} / \mathrm{mL}$ & $\begin{array}{l}\text { Patients with AT1R } \mathrm{Ab}(+) \text { had more } \mathrm{AMR} \text { and } \\
\text { microcirculation inflammation. }\end{array}$ \\
\hline $\begin{array}{l}\text { Philogene et al. } \\
\text { (2017) [27] }\end{array}$ & 70 & Post-KT & $10,17 \mathrm{U} / \mathrm{mL}$ & $\begin{array}{l}\text { AT1R Ab levels were higher in patients with } \\
\text { AMR than no rejection. Microcirculation } \\
\text { inflammation was higher in patients with } \\
\text { higher }(>17) \text { AT1R Ab. }\end{array}$ \\
\hline $\begin{array}{l}\text { Pinelli et al. } \\
\text { (2017) [38] }\end{array}$ & 142 & Pre \& post-KT & $17 \mathrm{U} / \mathrm{mL}$ & No statistical association was found. \\
\hline $\begin{array}{l}\text { Fichtner et al. } \\
\text { (2018) [28] }\end{array}$ & 62 (Pediatric) & Post-KT & $9.5 \mathrm{U} / \mathrm{mL}$ & $\begin{array}{l}\text { AT1R Ab was associated with AMR and adverse } \\
\text { graft outcome. }\end{array}$ \\
\hline $\begin{array}{l}\text { Gareau et al. } \\
\text { (2018) [33] }\end{array}$ & 101 & Pre \& post-KT & $17 \mathrm{U} / \mathrm{mL}$ & $\begin{array}{l}\text { Pre-KT AT1R Ab were more likely to develop } \\
\text { de novo DSA and associated with early T cell } \\
\text { mediated rejection. }\end{array}$ \\
\hline $\begin{array}{l}\text { Min et al. } \\
\text { (2018) [14] }\end{array}$ & 359 & Pre-KT & $10 \mathrm{U} / \mathrm{mL}$ & $\begin{array}{l}\text { Microvascular inflammation was associated with } \\
\text { pre-KT AT1R Ab. } \\
\text { Pre-KT AT1R Ab was an independent risk } \\
\text { factor for allograft failure. }\end{array}$ \\
\hline $\begin{array}{l}\text { Pearl et al. } \\
\text { (2018) [13] }\end{array}$ & 65 (Pediatric) & Pre \& post-KT & $17 \mathrm{U} / \mathrm{mL}$ & $\begin{array}{l}\text { Demonstrated association between AT1R Ab and } \\
\text { allograft loss, decline in renal function and } \\
\text { vascular inflammation. }\end{array}$ \\
\hline $\begin{array}{l}\text { Philogene et al. } \\
\text { (2018) [32] }\end{array}$ & 170 & Pre-KT & $17 \mathrm{U} / \mathrm{mL}$ & $\begin{array}{l}\text { Patients with pre-KT AT1R Ab had increased } \\
\text { post-KT serum creatinine levels and developed } \\
\text { abnormal biopsy findings. }\end{array}$ \\
\hline
\end{tabular}

AT1R, angiotensin II type 1 receptor; KT, kidney transplantation; NA, not available; Ab, antibody; DSA: donor-specific human leukocyte antigen antibody; MICA, major histocompatibility complex class I chain-related gene A; AMR, antibody-mediated rejection; HLA, human leukocyte antigen. 
AT1R expression by immunohistochemical staining using specimens of biopsies for recipients suspected of graft insufficiency after transplantation. Of 118 patients, 42 (35.6\%) showed AT1R expression in tubular epithelial cells. The incidence of graft failure after 1 year was significantly higher in this group with AT1R expression than that in those without AT1R expression. Their study is meaningful in that AT1R expression is directly observed in the graft tissue with clinical significance.

\section{TREATMENT OF AT1R ANTIBODY-MEDIATED REJECTION}

To date, no standardized treatment has been established for AT1R antibody-mediated rejection (AT1R-AMR). Rejections mediated by AT1R antibody are usually not responsive to steroids. They are known to be accompanied by hypertension [41]. However, there have been several reports of successful treatment for AT1R-AMR with plasmapheresis combined with immunoglobulin, antithymocyte globulin, and AT1R blocker (ARB) or rituximab [8,11,31,36,41]. Recently, Yamada et al. [20] have reported two cases of effective treatment through plasmapheresis. One patient was treated with ARB plus plasmapheresis while the other patient was treated with plasmapheresis alone. In both patients, transient reduction of antibody titers and clinical improvement were observed immediately after plasmapheresis. However, antibody titers elevated again. Thus, further plasmapheresis procedures were performed. This suggests the importance of AT1R antibody titer monitoring in patients with AT1R-AMR.

\section{CONCLUSIONS}

With the development of assay that facilitates the measurement of DSA and AT1R antibodies, pathological role and clinical usefulness of AT1R antibodies in KT have been highlighted. Several studies have been conducted to identify patients with rejection or graft failure due to non-HLA antibodies by monitoring AT1R antibodies. However, the exact mechanism about how AT1R antibodies cause tissue damage has not been recognized. Based on results of reported studies so far, AT1R antibody test may be useful for patients without DSA or with suspected graft dysfunction after transplantation. Further studies on the mechanism of AT1R-AMR, establishment of cutoff value for AT1R antibody positivity, and effective treatment of AT1R-AMR will contribute to the improvement of organ transplantation.

\section{CONFLICT OF INTEREST}

No potential conflict of interest relevant to this article was reported.

\section{ORCID}

Hyeyoung Lee https://orcid.org/0000-0001-8871-5091

Eun-Jee Oh https://orcid.org/0000-0001-5870-915X

\section{REFERENCES}

1. Michielsen LA, van Zuilen AD, Krebber MM, Verhaar MC, Otten HG. Clinical value of non-HLA antibodies in kidney transplantation: still an enigma? Transplant Rev (Orlando) 2016;30:195-202.

2. Zhang Q, Reed EF. The importance of non-HLA antibodies in transplantation. Nat Rev Nephrol 2016;12:484-95.

3. Oh EJ, Park H, Park KU, Kang ES, Kim HS, Song EY. Interlaboratory comparison of the results of lifecodes LSA class I and class II single antigen kits for human leukocyte antigen antibody detection. Ann Lab Med 2015;35:321-8.

4. Loupy A, Lefaucheur C, Vernerey D, Prugger C, Duong van Huyen JP, Mooney N, et al. Complement-binding anti-HLA antibodies and kidney-allograft survival. N Engl J Med 2013;369:1215-26.

5. Racusen LC, Haas M. Antibody-mediated rejection in renal allografts: lessons from pathology. Clin J Am Soc Nephrol 2006;1:415-20.

6. Colvin RB. Antibody-mediated renal allograft rejection: diagnosis and pathogenesis. J Am Soc Nephrol 2007;18: 1046-56.

7. Opelz G; Collaborative Transplant Study. Non-HLA transplantation immunity revealed by lymphocytotoxic antibodies. Lancet 2005;365:1570-6.

8. Dragun D, Müller DN, Bräsen JH, Fritsche L, NieminenKelhä M, Dechend R, et al. Angiotensin II type 1-receptor activating antibodies in renal-allograft rejection. $\mathrm{N}$ Engl J Med 2005;352:558-69.

9. Reinsmoen NL, Lai CH, Heidecke H, Haas M, Cao K, Ong 
G, et al. Anti-angiotensin type 1 receptor antibodies associated with antibody mediated rejection in donor HLA antibody negative patients. Transplantation 2010;90:1473-7.

10. Giral M, Foucher Y, Dufay A, Van Huyen JP, Renaudin K, Moreau A, et al. Pretransplant sensitization against angiotensin II type 1 receptor is a risk factor for acute rejection and graft loss. Am J Transplant 2013;13:2567-76.

11. Taniguchi M, Rebellato LM, Cai J, Hopfield J, Briley KP, Haisch CE, et al. Higher risk of kidney graft failure in the presence of anti-angiotensin II type-1 receptor antibodies. Am J Transplant 2013;13:2577-89.

12. Lee J, Huh KH, Park Y, Park BG, Yang J, Jeong JC, et al. The clinicopathological relevance of pretransplant anti-angiotensin II type 1 receptor antibodies in renal transplantation. Nephrol Dial Transplant 2017;32:1244-50.

13. Pearl MH, Zhang Q, Palma Diaz MF, Grotts J, Rossetti M, Elashoff D, et al. Angiotensin II type 1 receptor antibodies are associated with inflammatory cytokines and poor clinical outcomes in pediatric kidney transplantation. Kidney Int 2018;93:260-9.

14. Min JW, Lee H, Choi BS, Park CW, Yang CW, Kim YS, et al. Clinical impact of pre-transplant antibodies against angiotensin II type I receptor and major histocompatibility complex class I-related chain A in kidney transplant patients. Ann Lab Med 2018;38:450-7.

15. Sevá Pessôa B, van der Lubbe N, Verdonk K, Roks AJ, Hoorn EJ, Danser AH. Key developments in renin-angiotensinaldosterone system inhibition. Nat Rev Nephrol 2013;9: 26-36.

16. Dragun D, Catar R, Kusch A, Heidecke H, Philippe A. Non-HLA-antibodies targeting angiotensin type 1 receptor and antibody mediated rejection. Hum Immunol 2012; 73:1282-6.

17. Elton TS, Martin MM. Alternative splicing: a novel mechanism to fine-tune the expression and function of the human AT1 receptor. Trends Endocrinol Metab 2003;14:66-71.

18. Miller JA, Scholey JW. The impact of renin-angiotensin system polymorphisms on physiological and pathophysiological processes in humans. Curr Opin Nephrol Hypertens 2004;13:101-6.

19. Rüster C, Wolf G. Angiotensin II as a morphogenic cytokine stimulating renal fibrogenesis. J Am Soc Nephrol 2011; 22:1189-99.

20. Yamada C, Huang Y, Norman S, Naik A, Moussa O, Samaniego M, et al. Efficacy of therapeutic plasma exchange on angiotensin II type-1 receptor antibodies on two kidney transplant recipients. J Clin Apher 2018;33:673-7.

21. Dzau VJ. Theodore cooper lecture: tissue angiotensin and pathobiology of vascular disease: a unifying hypothesis.
Hypertension 2001;37:1047-52.

22. Cresci B, Giannini S, Pala L, Mavilia C, Manuelli C, Cappugi $\mathrm{P}$, et al. AT1 and AT2 receptors in human glomerular endothelial cells at different passages. Microvasc Res 2003; 66:22-9.

23. Wallukat G, Homuth V, Fischer T, Lindschau C, Horstkamp B, Jüpner A, et al. Patients with preeclampsia develop agonistic autoantibodies against the angiotensin AT1 receptor. J Clin Invest 1999;103:945-52.

24. Dragun D, Catar R, Philippe A. Non-HLA antibodies in solid organ transplantation: recent concepts and clinical relevance. Curr Opin Organ Transplant 2013;18:430-5.

25. Reinsmoen NL. Role of angiotensin II type 1 receptoractivating antibodies in solid organ transplantation. Hum Immunol 2013;74:1474-7.

26. Dragun D. The role of angiotensin II type 1 receptor-activating antibodies in renal allograft vascular rejection. Pediatr Nephrol 2007;22:911-4.

27. Philogene MC, Bagnasco S, Kraus ES, Montgomery RA, Dragun D, Leffell MS, et al. Anti-angiotensin II type 1 receptor and anti-endothelial cell antibodies: a cross-sectional analysis of pathological findings in allograft biopsies. Transplantation 2017;101:608-15.

28. Fichtner A, Süsal C, Schröder C, Höcker B, Rieger S, Waldherr $\mathrm{R}$, et al. Association of angiotensin II type 1 receptor antibodies with graft histology, function and survival in paediatric renal transplant recipients. Nephrol Dial Transplant 2018;33:1065-72.

29. Banasik M, Boratyńska M, Kościelska-Kasprzak K, Kamińska D, Bartoszek D, Zabińska M, et al. The influence of non-HLA antibodies directed against angiotensin II type 1 receptor (AT1R) on early renal transplant outcomes. Transpl Int 2014;27:1029-38.

30. Lee H, Kim JI, Moon IS, Chung BH, Yang CW, Kim Y, et al. Investigation of serum angiotensin II type 1 receptor antibodies at the time of renal allograft rejection. Ann Lab Med 2015;35:314-20.

31. Fuss A, Hope CM, Deayton S, Bennett GD, Holdsworth R, Carroll RP, et al. C4d-negative antibody-mediated rejection with high anti-angiotensin II type I receptor antibodies in absence of donor-specific antibodies. Nephrology (Carlton) 2015;20:467-73.

32. Philogene MC, Zhou S, Lonze BE, Bagnasco S, Alasfar S, Montgomery RA, et al. Pre-transplant screening for non-HLA antibodies: who should be tested? Hum Immunol 2018;79:195-202.

33. Gareau AJ, Wiebe C, Pochinco D, Gibson IW, Ho J, Rush DN, et al. Pre-transplant AT(1)R antibodies correlate with early allograft rejection. Transpl Immunol 2018;46:29-35. 
34. Cuevas E, Arreola-Guerra JM, Hernández-Méndez EA, Salcedo I, Castelán N, Uribe-Uribe NO, et al. Pretransplant angiotensin II type 1-receptor antibodies are a risk factor for earlier detection of de novo HLA donor-specific antibodies. Nephrol Dial Transplant 2016;31:1738-45.

35. Deltombe C, Gillaizeau F, Anglicheau D, Morelon E, Trébern-Launay K, Le Borgne F, et al. Is pre-transplant sensitization against angiotensin II type 1 receptor still a risk factor of graft and patient outcome in kidney transplantation in the anti-HLA Luminex era? A retrospective study. Transpl Int 2017;30:1150-60.

36. Lee J, Park Y, Kim BS, Lee JG, Kim HJ, Kim YS, et al. Clinical implications of angiotensin II type 1 receptor antibodies in antibody-mediated rejection without detectable donor-specific HLA antibodies after renal transplantation. Transplant Proc 2015;47:649-52.

37. Lim MA, Palmer M, Trofe-Clark J, Bloom RD, Jackson A, Philogene MC, et al. Histopathologic changes in anti-angiotensin II type 1 receptor antibody-positive kidney transplant recipients with acute rejection and no donor specific HLA antibodies. Hum Immunol 2017;78:350-6.

38. Pinelli DF, Friedewald JJ, Haarberg KM, Radhakrishnan SL, Zitzner JR, Hanshew WE, et al. Assessing the potential of angiotensin II type 1 receptor and donor specific anti-endothelial cell antibodies to predict long-term kidney graft outcome. Hum Immunol 2017;78:421-7.

39. Martin L, Guignier F, Mousson C, Rageot D, Justrabo E, Rifle G. Detection of donor-specific anti-HLA antibodies with flow cytometry in eluates and sera from renal transplant recipients with chronic allograft nephropathy. Transplantation 2003;76:395-400.

40. Sas A, Donizy P, Kościelska-Kasprzak K, Kamińska D, Mazanowska O, Krajewska M, et al. Histopathological relevance of angiotensin II type 1 receptor in renal transplant biopsy. Transplant Proc 2018;50:1847-9.

41. Jobert A, Rao N, Deayton S, Bennett GD, Brealey J, Nolan $\mathrm{J}$, et al. Angiotensin II type 1 receptor antibody precipitating acute vascular rejection in kidney transplantation. Nephrology (Carlton) 2015;20 Suppl 1:10-2. 